\title{
Communication Studies as Social Science: Trajectories of the evolvement and institutionalization of the socio-scientific paradigm in German Communication Studies, 1960s - 1980s
}

\author{
Os estudos de comunicação como ciência social: As trajetórias de \\ desenvolvimento e institucionalização do paradigma científico-social nos \\ estudos de comunicação alemães, 1960-1980.
}

\section{Erik Koenen}

Pós-doutor em Comunicação, pesquisador associado no Centro de Pesquisa em Mídia, Comunicação e Informação da Universidade de Bremen. Dedica-se à pesquisa da história teorética dos estudos de comunicação. <ekoenen@uni-bremen.de>

\section{Christina Sanko}

Pesquisadora associada no Centro de Pesquisa em Mídia, Comunicação e Informação da Universidade de Bremen. Possui mestrado pela Universidade de Leipzig. Dedica-se à pesquisa sobre história da comunicação e análise de mudanças midiáticas. <sanko@uni-bremen.de>

\section{ABSTRACT}

The article focuses on the processes of the founding of German Communication Studies as social science from the 1960s to the 1980s. At the beginning of the 1960s, German "Publizistikwissenschaft" was a discipline on the edge. It suffered from an acute lack of academic staff as well as methodological and theoretical innovations. Therefore, the discipline was no longer supported by German higher education politics. The eventual rescue of the discipline came from outside. The extension of the cognitive identity of "Publizistikwissenschaft" towards empirical socio-scientific communication studies was initiated by career changers and outsiders with more awareness for the need of modern social sciences. In the 1960s, Fritz Eberhard, Gerhard Maletzke, Elisabeth Noelle-Neumann, Henk Prakke, Otto B. Roegele and others initiated a debate about the redefinition of the discipline's subject, including empirical methods and sociological theories. Thus, they induced an empirical turn of the discipline and prepared the institutionalization of the socio-scientific paradigm in German Communication Studies in the 1970s and 1980s.

Keywords: Communication. Media and Politics. Germany.

\section{RESUMO}

O artigo foca nos processos fundadores dos estudos de comunicação alemães como ramo da ciência social no período que vai dos anos 1960 aos 1980 . No início dele, a chamada "Publizistikwissenschaft" encontrava-se no limite como disciplina, sofrendo de grave falta de pessoal tanto quanto de inovações teóricas e metodológicas. A disciplina não tinha mais apoio da política alemã de ensino superior. $\mathrm{O}$ resgate da disciplina veio de fora, originou-se da ação de forasteiros mais atentos às necessidades das ciências sociais contemporâneas, que empurraram a identidade cognitiva da velha disciplina na direção dos estudos de comunicação científico-sociais empíricos. Nos 1960, Fritz Eberhard, Gerhard Maletzke, Elisabeth Noelle-Neumann, Henk Prakke, Otto B. Roegele e outros iniciaram um debate visando redefinir o seu objeto de estudo, incluindo os métodos empíricos e as teorias sociológicas. Assim, eles ensejaram uma virada empírica na matéria e prepararam a institucionalização do paradigma científico nos estudos de comunicação alemães ocorrida nos anos 1970 e 1980. 
This overview represents a sequel of Stefanie Averbeck-Lietz's (2014) article [published in this journal] on the history of German Communication Studies that examined the origins of the discipline and its development until the late 1950s. It focuses particularly on the phase, Averbeck-Lietz (2014) identified as "Redefinition of the discipline as Social Science Research" (1960 - end of 1980s). Academic debates and controversies on the so-called socio-scientific turn and the development and institutionalization of the socio-scientific paradigm in German Communication Studies create the core of this work. On the basis of a synopsis of available historical research on the discipline the article outlines four significant stages of the disciplinary change from "Publizistikwissenschaft" to communication studies as social science until the end of the 1980s: (1) the field's political point of departure at the beginning of the 1960s, (2) the empirical socio-scientific turn, (3) the dislimitation of communication studies and (4) the consolidation of the discipline's cognitive and social identity.

\section{Communication studies's political point of departure: a discipline on the edge}

Despite its recommencement after 1945 and the promising reconstruction of the discipline's identity as "Publizistikwissenschaft" that proceeded the radical alteration of the discipline during the Third Reich, the development of German Communication studies stagnated again by the late 1950s. On the one hand, scientific administration still faced the issue of recruiting young academics. On the other hand, the prevalent organizational form of one-professorship institutes impeded the search for eligible successors. In consequence, the remaining post-war instituts in Berlin, Munich and Münster were directly linked to the names of Emil Dovifat, Karl d'Ester and Walter Hagemann (Bohrmann, 2002; Stöber, 2002). The issue became evident by the beginning of the 1960s, when Walter Hagemann, who represented the "powerful center of the academic field" (Wiedemann, 2012, p. 366), ${ }^{1}$ was suspended from the university and eventually even emigrated to the German Democratic Republic (GDR) in 1961. Reasons were his criticism and political commitment against Konrad Adenauer's foreign politics of allying Germany with Western powers and the rearmament of the Federal Republic. His public degradation fuelled "a deep crisis of the academic discipline that he personified" (Wiedemann, 2012, p. 370), also "because at the time Karl d'Esters's succession (by Hanns Braun) in Munich was hardly convincing

1 All German quotations are translated by the authors. 
and the upcoming succession of Emil Dovifats was complicated" (Bohrmann, 2002, p. 27).

The issue of finding suitable successors and young academics made up one reason for German higher education politics to declare the discipline's probable end (Meyen and Löblich, 2006, p. 68). Recommendations on the expansion of scientific bodies presented by the German Council of Science and Humanities in the 1960s classified the discipline as a "special field". In 1964, the Standing Conference of the Ministers of Education and Cultural Affairs ${ }^{2}$ ignored "Publizistikwissenschaft" completely and instead encouraged political science, psychology, sociology, law and economics to devote more research to "mass media and the relations between communication, state and society" (Kutsch and Pöttker, 1997, p. 7-8).

Another reason for the deep skepticism of German higher education politics was the discipline's resistance against a substantial epistemological enhancement of its conceptualization beyond a mere redefinition of subjects of interest (see overview by Löblich, 2010, p. 107). The insistence on exclusivity of the object of research and methodological and theoretical autonomy reactivated a "pattern of justification" (Löblich, 2010, p. 109) of the Weimar Newspaper Science that at the time preferred exclusivity instead of interdisciplinarity and thus surpressed the trend of an establishing innovative milieu, linking newspaper and social sciences (Averbeck, 1999; 2001). Theoretically and methodologically "Publizistikwissenschaft" was rather assigned to the humanities: "Terms and definitions were the epistemological point of departure" that focused on "the 'essence' of media" (Löblich, 2010, p. 112-113). It was not of interest to explain functions of communication processes, but to understand these as "linear processes of persuasion" and to teach future journalists normative "knowledge on media and propaganda for orientation purposes" (Löblich, 2010, p. 111114). Therefore, not only the acute lack of academic staff, but also the limited humanities approach was responsible for the deciding higher education and political bodies not being convinced of the need of the discipline: neither was the discipline interdisciplinary connectable and competitive, nor did it provide the expected and needed knowledge on media and communication processes. "The reformed ,Publizitikswissenschaft" was not even able to claim exclusive

2 The Standing Conference of the Ministers of Education and Cultural Affairs [...] plays a significant role as an instrument for the coordination and development of education in the country. It is a consortium of ministers responsible for education and schooling, institutes of higher education and research and cultural affairs, and in this capacity formulates the joint interests and objectives of all 16 federal states." See: <https://www.kmk.org/kmk/information-in-english.html> [15 february 2016]. 
responsibility for basic communication research any more", Arnulf Kutsch and Horst Pöttker (1997, p. 12) sum up the state of the discipline by the beginning of the 1960s. Hans Bohrmann (1997, p. 57) states that the discipline at that time had basically reached the end of the road.

\section{First reorientation from "Publizistikwissenschaft" to communication studies: delimitation and modernization in the $1960 \mathrm{~s}$}

In retrospective, the virtue made out of the necessity of academic staff contributed to the overcoming of the existential crisis of the academic discipline: a new generation of professors was appointed who was "little or not at all connected to the 'old' discipline" (Meyen and Löblich, 2006, p. 33). These new professors were unreserved and did not hesitate to break with the conceptualization of "Publizistikwissenschaft". They aimed at reforming the discipline theoretically and methodologically and thus opening it up for interdisciplinary and international cooperation. Helpful was the fact that the new staff's backgrounds were mainly in journalism and the larger field of media practice. Therefore, they were mostly socialized in different disciplines during their studies (overview on collective biographies by Meyen, 2007, p. 26). According to Hans Bohrmann (2002, p. 32), the post-war recommencement of the discipline rates poorly, regarding that the socioscientific turn was initiated by the emigrated journalist and politician Fritz Eberhard (FU Berlin), the Dutch sociologist Henk Prakke (Münster) and Otto B. Roegele (Munich), who grew up in the midst of Catholic youth resistance, only by the end of the 1960s. Eberhard, Prakke, Roegele as well as Elisabeth Noelle-Neumann and Harry Pross were outsiders and career changers who, in contrast to their predecessors, recognized the urgent need for reforms of the discipline.

The protagonists who joined the discipline in the course of the 1960s, set scientific respectability for the necessary support by higher education politics high up on their agenda. It allowed for the institutional consolidation and prospective expansion of the academic field. Despite many disagreements (overview on single standpoints by Löblich, 2010, p. 130), they introduced a process of vast socio-scientific modernization that aimed at overcoming the "sole 'phenomenologically' founded identity" of "Publizistikwissenschaft" (Kutsch and Pöttker, 1997, p. 12). In other words, this meant "orientation towards US-American communication research, critical rationalism or positivism, strong consciousness about methods, application of quantitative measures, formulation of theoretical and empirically verifiable hypotheses as well as references to the presence and applied approaches." (Löblich, 2010, p. 151). Elisabeth Noelle- 
Neumann, professor of the in 1965 newly established chair in communication at the University of Mainz and one of the key figures of the empirical socioscientific turn, summed up the expected gain of insights following the reinnovation of the discipline as a social science: "If this richness in empirical observations and if the capacities of these observation instruments will serve the discipline of ,Publizistikwissenschaft', we can expect a vivid, more realistic, human, productive, better backed and formulated 'Publizistikwissenschaft."' (1963, p. 323; see also the autobiographical report: Noelle-Neumann, 1997) Otto B. Roegele, director of the insitute in Munich since 1963, valued the socioscientific reorientation of "Publizistikwissenschaft" almost isochronically and in similar line of thought in 1965: "The plentiness of new methods and research questions that are provided by empirical sociology and socio-psychology and the rapid technical progress in the area of electronic media, gear from a past perspective towards the present. The present changes so fast that you are afraid of loosing track if you do no pay attention for a moment" (Roegele as cited in Langenbucher, 2006, p. 4).

Besides the common plea for an intensified use of empirical methods to solve present questions and issues in communications, representatives of the socioscientific reorientation strongly related to thoughts, concepts and theories from politics, socio-psychology or sociology, also receiving US-American Mass Communication Research. This can be exemplified by the interdisciplinary and transnational transfer of ideas by Fritz Eberhard, who reconceptualized the formal object of the communication process with the help of the Lasswell formula: "Let us rethink the communication process according to the Lasswell formula, which proceeds from the communicator via the message - through the medium - to the receiver". That requires the examination of "a very complex interplay of individuals" on the one hand, and the investigation of "a complex, here only suggested, process that involves technical, economic, organizational, psychological and sociological factors" on the other hand. With regard to a disciplinary exclusivity in gaining knowledge and solutions to scientific problems, Eberhard (1961, p. 263) understands all these elements as "subject of 'Publizistikwissenschaft' and no other discipline". While Fritz Eberhard included the social context of the communication processes into the epistemological interest of the discipline, others such as Henk Prakke dissolved the unidimensional modeling. With his functional approach, Prakke was the first to create "a modell of the communication process on a sociological basis" (Averbeck, 2000, p. 59) that was found on a general "interactive relation between communicator and recipient" (Kutsch, 2000, p. 39; see more in detail on Klein, 2006): "If we want to 
understand the communicator (publicist), communication (message) and the recipient (reciever) as the three key positions of the communication process, the subject of a functional approach is the interdependency of these variable complexes," stated Prakke et al. (1968, p. 7).

That way Henk Prakke put forth a concept for the academic discipline that exceeded the field of "Publizistikwissenschaft". Instead of a linear-persuasive communication process, it focused on "social communication as formal object" and thus merged valuable perspectives in communication studies (Kutsch, 2000, p. 36): "Communication of society is social communication in both, interpersonal and mass mediated terms. Both forms are highly relevant for public communication" (Averbeck, 2000, p. 57-58). Prakke's advance therefore represented an important signal for the opening of epistemological perspectives from "Publizistikwissenschaft" towards communication studies. Despite the high degree of innovation and systematic integration in the state of the art of Mass Communication Research in the US this original proposal in theorybuilding did not succeed in communication studies. Prakke's basic dialogicaloriented formula "Alle Publizistik ist Zwiegespräch" with its orientation towards interpersonal communication was too unusual at the time (Westerbarkey, 2002; also: Meyen and Löblich, 2006, p. 240). Similarly treated were Harry Pross's extended approach towards communication studies with its principle "Der Mensch entsteht durch Kommunikation" [The human-being is created through communication] (Bentele, 2002) or Otto B. Roegele's statement of "Zeitgespräch der Gesellschaft" [Dialogue of society] that he used while trying to found a "science of social communication" (Langenbucher, 2006, p. 3).

The delimitation and extension of the cognitive identity of "Publizistikwissenschaft" towards empirical socio-scientific communication studies initiated by Henk Prakke, Harry Pross and Otto B. Roegele amongst others defined the disciplinary core interest as "the communication process, its determinants und its societal relations, particularly its psychological effects on the individual and its structural impacts on society" (Kutsch and Pöttker, 1997, p. 12) and anchored the integration of insights, lines of thought and concepts of US Mass Communication Research and thus the professionalization and standardization of the discipline. In recent communication studies history these efforts are mainly assigned to Gerhard Maletzke's key work Psychologie der Massenkommunikation [Psychology of mass communication]. Just as the above-mentioned colleagues, Maletzke had a fundamentally new "theory and classification" of the discipline in mind (Pöttker, 2002; also: Meyen and Löblich, 2006, p. 221). Although, Maletzke was never able to start a career and establish 
himself in the field as a communication scholar (Meyen and Löblich, 2011), communication historian Horst Pöttker regards his work from 1963 as a decisive "initial spark for the renewal of the discipline in the 1960s" (Pöttker, 2002, p. 291) during the process of cognitive delimitation and socio-scientific reorientation. Otto B. Roegele already saw Maletzke as "the bearer of a newly introduced socio-empirical and psychologically founded science from the anglo-saxon world that had spread with only fragments being known in German institutes" (Roegele cited by Meyen and Löblich, 2006, p. 221). Michael Meyen and Maria Löblich state that "the book eased work for university outsiders such as Fritz Eberhard und Otto B. Roegele and it satisfied the need for a recommencement, also because it offered a terminology that originated in the USA as a role model country and did not root in the own tradition" (Meyen and Löblich, 2006, p. 223). First and foremost, however, Maletzke "has given German communication studies an image besides 'a language.' Until today, his so-called 'field scheme of mass communication' [Feldschema der Massenkommunikation] shows first-year students 'at one glance' what the discipline deals with" (Meyen and Löblich, 2006, p. 226). Maletzke himself regarded his work in retrospective much more modest: "The time had come for communication studies in Germany. The discipline would have emerged and developed even without my 'influence ${ }^{\prime \prime \prime}$ (Maletzke, 1997, p. 113).

Gerhard Maletzke's mitigation of his own personal influence eventually hints at that the process of a cognitive reorientation of "Publizistikwissenschaft" to empirical socio-scientific communication studies was not only for internal reasons. The development was also triggered externally, as a "striking change of modern societies towards media societies with a greater need for solutions to related problems" took place (Kutsch and Pöttker, 1997, p. 12; for a history on German media society at that time see: Hodenberg, 2006). Societal and media change both generated a demand for valid knowledge about social and public communication. The massive pressure to change the discipline that was on the verge of closure created "convenient conditions for the implementation" (Kutsch and Pöttker, 1997, p. 10) of new concepts for the discipline, which exceeded established paradigms of German Newspaper Science and "Publizistikwissenschaft". In this regard, Maria Löblich explains the empirical socioscientific, including the cognitive delimitation of the discipline towards communication studies as a result of a complex process, "during which various driving forces overlapped and amplified": "The spread of television, press concentration and the functions of journalism for society triggered public debates. Media organizations and associations as well as media politicians had to 
react to such debates and therefore needed research results that allowed for the legitimization of political decisions and the arrangement of cooperate activities" (Löblich, 2010, p. 301, 302; on interactions between media research and media development see: Ronneberger, 1991). Research results then did not refer to "theorizing media criticism", but rather "representative data and immediately usable socioscientific findings" (Löblich, 2010, p. 302). The political research agenda on communication by the Federal Republic of Germany, running from 1970-1990s, illustrated this demand for concrete media knowledge. It helped communication studies in the phase of stabilization of the socioscientific paradigm to sustainibly gain reputation and ressources (Löblich, 2008).

\section{Stabilization of communication studies in the 1970s}

"German 'Publizistikwissenschaft' rose like a phoenix from the ashes" (Kutsch and Pöttker, 1997, p. 10) and recovered and stabilized as communication studies in the 1970s not only institutionally, but it also gradually gained scientific resepect. This emergence cannot solely be traced back to new methodological and theoretical stimuli and the establishment of an epistemology based on present communication-related questions and issues. It was at the same time a result of immense organizational and institutional efforts of a generation of "new founding fathers" (Meyen, 2007, p. 26) or "nestors" (Kutsch and Pöttker, 1997, p. 8-10) including Fritz Eberhard, Gerhard Maletzke, Elisabeth Noelle-Neumann, Henk Prakke, Harry Pross and Otto B. Roegele. Wolfgang R. Langenbucher (2006) reviewed Roegele's efforts among this generation and indicated the additional challenges for the consolidation of the cognitive and creative reorientation of the discipline during the 1970s: "1. Coping the 'mass university', 2. education of young academics, f.e. with four habilitations, 3. modernization of teaching and training in the journalism diploma programme (...), 4. activation of the institute as a research location (...) and 5. activities in political consultancy" (Langebucher, 2006, p. 6).

To push the institutional extension of the discipline, the first three points gained highest priority. By the beginning of the 1970s, a "permantly rising influx of students" into the study programme was notified (Noelle-Neumann, 1975, p. 744). Besides the requested research results by society, media, politics and higher education administration, it was now also students who increasingly demanded knowledge and practical skills in the field. With the growing social relevance of media, the attractiveness of a "functional and quantitatively expanding" professional field rose (Wilke, 2005/06, p. 333) and led to "a rapidly rising number of students of the discipline, including a type of students that 
was mainly professionally oriented“ (Kutsch and Pöttker, 1997, p. 13). Moreover, the model of the mass university in education politics stimulated additionally this demand. For the discipline itself, this booming demand by future media professionals was the crucial external factor for the institutional expansion. It led to the reactivation of a traditional but after 1945 largely neglected practical function of the discipline and "prompted long overdue efforts to include practical approaches into the teaching of communication studies at the universities" (Kutsch and Pöttker, 1997, p. 13). An immediate reaction of higher education politics was the establishment of profession-oriented study programmes at existing institutes but also at other universities in the course of the 1970s - "not only for journalists, but also for careers in public relations in particular (...) in other press and media professions, media pedagogy, media design and (applied meda research)" (Wilke, 2005/06, p. 333).

The expanding institutional fundament of communication studies followed by a continuous impetus of journalism and media training at universities in the 1970s and 1980s was not least to great benefit of the discipline's own young academics, who the new founding fathers had raised again for the first time with a wave of habilitations. This generation of so-called "young turks" entered the field and continued, "what the generation of 'new founding fathers' generally was only able to define as the objective" (for an overview of collective biographies see Meyen, 2007, p. 28; see also: Meyen and Löblich, 2007). In the long term, these "young turks" stabilized the organizational and research efforts of the "nestors", the disciplinary identity as integrative social science founded by them, and the newly gained scientific legitimacy and respectability of communication studies. The German communication encyclopedia FischerLexikon Publizistik mirrors the progress and accumulation of knowledge in the field. While the editors stated "striking gaps" in the introduction of the first edition in 1971 that forced them to collect "wide-spread" knowledge (NoelleNeumann and Schulz, 1971, p. 9), their foreword of the second edition (1989) was more pleasant: "Corresponding to the growing significance of its subject, no other academic discipline in social sciences has developed more strongly than communication research. (...) It has not only reached international standard; in some areas, communication research in Europe and not least in the Federal Republic even determines the trend of research again." (Noelle-Neumann et al., 1989, p. 7-8) The same year, a special issue Massenkommunikation [Mass communication] was published in the renowned sociological journal Kölner Zeitschrift für Soziologie und Sozialpsychologie [Cologne Journal of Sociology and Sociopsychology], presenting findings, approaches and problems of 
communication studies exclusively and prominently in the neighbouring socioscientific discipline of sociology for the first time (Kaase and Schulz, 1989).

A last collective organisational effort in science by the founding generation was the, after many failed attempts, successful foundation of a German scientific association Deutschen Gesellschaft für Publizistik- und Zeitungswissenschaft [German Association for Publizistikwissenschaft and Newspaper Science] in 1963. In 1972, the association was renamed in Deutsche Gesellschaft für Publizistik- und Kommunikationswissenschaft [German Communication Association], corresponding to "the change of the discipline" (Wilke, 2005/06, p. 328). First, the association functioned as an important discursive platform, whose conferences discussed not only theoretical topics, but also practical issues the discipline faced in the 1960s and 1970s, e.g. lacking reputation and staff, capacity overload of institutes following an afflux of students and a practical orientation of the study programme. Second, it served as an important driving force for the evolvement of a genuine scientific community in communication and thus advanced the process of stablization of an own specific cognitive and social identity. Reviewing the statistics of association members, a continuous trend of growth of the discipline can be notified. After only 50 members in the beginning, the number steadily increased (1976: 185; 1981: more than 230) to 350 members by the end of the 1980s (Wilke, 2005/06, p. 335).

\section{Resume: State of communication studies in the 1980 s}

Summarizing the complex processes of the emergence and institutionalization of the socioscientific paradigm in German Communication studies, it becomes visible how enormous the efforts of the new founding fathers in the 1960s and their successors were. Hans Bohrmann concludes the institutional and cognitive success and the gained scientific reputation as follows: "The discipline was able to wipe off its marginalization and became a ,normal science' that was requested by students, generally appreciated by the professional sector and not just condoned by neighbouring disciplines." (Bohrmann, 1997, p. 65) Protagonists of the discipline at that time came to similar conclusions as a survey amongst chairs and directors of institutes and study programmes of communication studies by Friedhelm Kröll (1980) showed. The responsibles in communication studies identified three advancements in the field: First, the discipline "was established as social science, away from a sole 'historiography' [...]"; second, the evolvement of a fundamentally interdisciplinary nature of the discipline as "integrative discipline"; and third, "the practical 
orientation or the decided openness of the discipline for social issues" (Kröll, 1980, p. 507). At the same time, they state that the overall pleasing disciplinary "differentiation of the variety of competencs in teaching and research" (Kröll, 1980, p. 495) and its function as research, training and teaching discipline for the professional sector is connected to major problems that cannot be completely solved given the current financial ressources and staff. While one faces the afflux of students that continuously "uses if not overburdens teaching capacities", "a discrepancy develops between the multidimensional bulge of communication studies during the last decades, the addition of plenty of new problem areas (...) and the availability of positions and staff skilled in these competencies at the institutes/study programs" (Kröll, 1980, p. 495; see also "bestürzende Bilanz" by Westerbarkey, 1980). Among representatives of the discipline, this was not only regarded as an issue to be solved with the demand for better ressources and staff. Rather, the situation of the discipline was seen as a neccessity to question the always as constitutive stressed momentum of "problem-oriented flexibility" (Kröll, 1980, p. 507) in the dimension of cognitive identity of communication studies. The survey showed a "tense and partly contradictory image" when it came to problem-solving strategies: On the one hand, there was "the option for the awareness of determining disciplinary boundaries; on the other hand, there was "the determination of the discipline as a seismographic and praxeological organ, depending on emerging social problems in the field of,communication "' (Kröll, 1980, p. 508).

The supporters of the first option emphasized that a continuously uncontrolled expansion of the subjects of communication studies could not be handled appropriately given the available means. Moreover, it would not be possible to found an exclusive disciplinary perspective in the long run while the "steady segmentation and agglomeration" (Franz Ronneberger cited in Kröll, 1980 , p. 507) of the discipline goeson. On the contrary, the continuing delimitation of the discipline would blurr noticeably the cognitive identity and gambles the just gained scientific reputation away. Under the heading of "Konkretion der Disziplin" [concretion of the disciplin] (Kröll, 1980, p. 508), they pledged for a "diminution of the program and a focus on essentials" (Ulrich Neveling, FU Berlin), the "consciousness about core issues" (Kurt Koszyk, Universität Dortmund) or a "limitation of the discipline with concurrent development of a professional specialization" (Michael Schmolke, Universität Salzburg) (Kröll, 1980, p. 507). Contrary, supporters of an basically open perspective and accordingly "encompassing conception" of communication studies such as Winfried B. Lerg (Universität Münster) suggested that just "because the discipline is a,integrative 
discipline', 'no subject can be determined in a way it is still possible for other disciplines"' (Kröll, 1980, p. 507).

Therefore, the fundamental understanding of the disciplinary core subject "communication" differed between these two fractions. The broad definition of communication als societal or social communication as supported by e.g. Lerg and Roegele opposed more narrow positions by Koszyk, Noelle-Neumann and Ronneberger, who described a more concentrated, clipped focus on "the area of 'questions of public and media-bound communication', in short, of 'public communication" "' (Kröll, 1980, p. 508). All representatives, however, agreed on the most pressing challenge of the discipline to formulate its theoretical foundations of communication studies and thus "to reduce theory deficits" (Kröll, 1980, p. 509). Yet, the survey overall demonstrates a controversial portrait of the state of the discipline in the 1980s. It shows that the genesis of the discipline passed less and less concerted on the one hand. On the other hand, disciplinary concepts pluralized which led to a increasingly vague, encompassing and consensual cognitive identity in regard to epistemological interests, subjects an objectives. In the meantime, Roegele took the looming issue on the cognitive constitution rather easy because he knew that sciences can be determined conditionally at the end of the day: "There are several communication studies," Ronneberger stated in this context and warned about an imminent "explosion of communcation studies" (Kröll, 1980, p. 507, 509). He justified his fears by stating: "With the change to communication studies the discipline has overstreched its area of studies and now has to worry about its credibility as scientific discipline" (Ronnenberger, 1986, p. 86). Thus, he summed up the core issue of the debate on a disciplinary subject, boundaries and objectives of the field by the beginning of the 1980s. By taking the communication term as basis, the discipline lost contours in a way that "every sociologist and psychologist, every linguist and historian, every political scientist and economist can name themselves communication scholars if they deal with the ,relations' among living beings or machines" (Ronnenberger, 1986, p. 87).

The poles of continuous expansion or disciplinary concentration that mark the positions of the protagonist in the issue of disciplinary consitution indicate that underneath the surface of institutional stabilization and growing scientific and social prestige the perspective of the discipline was increasingly controversial. Still, the discipline had not found a way to formulate a "specific, substantial, disciplinary perspective" (Saxer, 1995, p. 42) that was open enough for the challenges of society, media and the public as well as the corresponding scientific pressure, and at the same time secured the cognitive identity. "Of 
course, the horizon of communication studies expands steadfast. It can indeed be regarded as permanent expansion. Where is the centre, where can we find solid grounds?," as editors of the German journal Publizistik described the issue (as cited in Holtz-Bacha et al., 2005/06, p. 439) that would bother German Communication studies in increasingly heated debates and disputes beyond the 1980s.

\section{Works cited}

AVERBECK, Stefanie. Kommunikation als Prozess. Soziologische Perspektiven in der Zeitungswissenschaft 1927-1934. Münster: Lit Verlag, 1999.

AVERBECK, Stefanie. Die funktionale Publizistik. Eine kritische Würdigung. In: HEMELS, Joan; KUTSCH, Arnulf; SCHMOLKE, Michael (eds.). Entgrenzungen. Erinnerungen an Henk Prakke. Assen: Van Gorcum, p. 57-71, 2000.

AVERBECK, Stefanie. Die Emigration der Zeitungswissenschaft nach 1933 und der Verlust sozialwissenschaftlicher Perspektiven in Deutschland. In: Publizistik, v. 46, n. 1, p. 1-19, 2001. <http://dx.doi.org/10.1007/s11616-001-0001-x>

AVERBECK-LIETZ, Stefanie. Da ciência do periódico à "ciência da liderança nacionalsocialista": como os estudos de imprensa adotaram o regime nazista na Alemanha. In: Revista FAMECOS, v. 21, n. 2, p. 418-437, 2014.

BENTELE, Günter. Harry Pross, Publizistik. Thesen zu einem Grundcolloquium (1970). In: HOLTZ-BACHA, Christina; KUTSCH, Arnulf (eds.). Schlüsselwerke für die Kommunikationswissenschaft. Wiesbaden: Westdeutscher Verlag, p. 353356, 2002.

BOHRMANN, Hans. Zur Geschichte des Faches Kommunikationswissenschaft seit 1945. In: FÜNFGELD, Hermann; MAST, Claudia (eds). Massenkommunikation. Ergebnisse und Perspektiven. Festschrift für Gerhard Maletzke. Opladen: Westdeutscher Verlag, p. 51-67, 1997.

BOHRMANN, Hans. Als der Krieg zu Ende war. Von der Zeitungswissenschaft zur Publizistik. In: Medien \& Zeit, v. 17, n. 2-3, p. 12-33, 2002.

EBERHARD, Fritz. Thesen zur Publizistikwissenschaft. In: Publizistik, v. 6, n. 5-6, p. 259266, 1961.

HODENBERG, Christina von. Konsens und Krise. Eine Geschichte der westdeutschen Medienöffentlichkeit 1945-1973. Göttingen: Wallstein Verlag, 2006.

HOLTZ-BACHA, Christina; KUTSCH, Arnulf; LANGENBUCHER, Wolfgang R.; SCHÖNBACH, 
Klaus. Rückblicke, Bilanzen, Programme. Editorials und Vorworte aus den Jahren 1976-2005. In: HOLTZ-BACHA, Christina; KUTSCH, Arnulf; LANGENBUCHER, Wolfgang R.; SCHÖNBACH, Klaus (eds.). 50 Jahre Publizistik. Wiesbaden: VS, p. 425-448, 2005/06.

KAASE, Max; SCHULZ, Winfried (eds.). Massenkommunikation. Theorien, Methoden, Befunde. Kölner Zeitschrift für Soziologie und Sozialpsychologie Sonderheft, v. 30, 1989.

KLEIN, Petra. Henk Prakke und die funktionale Publizistik. Über die Entgrenzung der Publizistik- zur Kommunikationswissenschaft. Münster: Lit Verlag, 2006.

KRÖLL, Friedhelm. Kommunikationswissenschaft. Auswertung einer Umfrage zur Entwicklung und Situation des Faches im deutschsprachigen Raum. In: Publizistik, v. 25, n. 4, p. 492-514, 1980.

KUTSCH, Arnulf. Die Öffnung der publizistikwissenschaftlichen Erkenntnisperspektive. In: HEMELS, Joan; KUTSCH, Arnulf; SCHMOLKE, Michael (eds.). Entgrenzungen. Erinnerungen an Henk Prakke. Assen: Van Gorcum, p. 27-42, 2000.

KUTSCH, Arnulf; PÖTTKER, Horst. Kommunikationswissenschaft autobiographisch. Einleitung in: KUTSCH, Arnulf; PÖTTKER, Horst (eds.). Kommunikationswissenschaft - autobiographisch. Zur Entwicklung einer Wissenschaft in Deutschland. Opladen: Westdeutscher Verlag, p. 7-20, 1997. $<$ http://dx.doi.org/10.1007/978-3-663-01167-5>

LANGENBUCHER, Wolfgang R. Otto B. Roegele: Der Zeitungswissenschaftler als Kommunikationswissenschaftler. 2006. In: Münchener Beiträge zur Kommunikationswissenschaft, n. 4. Disponível em: <https://epub.ub.unimuenchen.de/935/1/mbk 4.pdf> Acesso em 15 jan. 2016.

LÖBLICH, Maria. Das kommunikationswissenschaftliche Forschungsprogramm der Bundesregierung und der Wandel der Publizistikwissenschaft zu einer empirischen Sozialwissenschaft. In: RAABE, Johannes; STÖBER, Rudolf, THEISBERGLMAIR, Anna Maria \& WIED, Kristina (eds.). Medien und Kommunikation in der Wissensgesellschaft. Konstanz: UVK, p. 297-314, 2008.

LÖBLICH, Maria. Die empirisch-sozialwissenschaftliche Wende in der Publizistikund Zeitungswissenschaft. Köln: Herbert von Halem, 2010.

MALETZKE, Gerhard. Erlebte Kommunikationswissenschaft im Rückblick. In: KUTSCH, Arnulf; PÖTTKER, Horst (eds.). Kommunikationswissenschaft autobiographisch. Zur Entwicklung einer Wissenschaft in Deutschland. Opladen: Westdeutscher Verlag, p. 110-119, 1997.

MEYEN, Michael. Geschichte der Kommunikationswissenschaft als Generationsgeschichte. Über den Einfluss prägender Lebenserfahrungen 
der zentralen Akteure auf die Entwicklung einer akademischen Disziplin im deutschsprachigen Raum. In: Studies in Communication Sciences, v. 7, n. 1, p. 11-37, 2007.

MEYEN, Michael; LÖBLICH, Maria. Klassiker der Kommunikationswissenschaft. Fachund Theoriegeschichte. In Deutschland: Konstanz/UVK, 2006.

MEYEN, Michael; LÖBLICH, Maria. "Ich habe dieses Fach erfunden." Wie die Kommunikationswissenschaft an die deutschsprachigen Universitäten kam. Köln: Herbert von Halem, 2007.

MEYEN, Michael; LÖBLICH, Maria. Gerhard Maletzke. Eine Geschichte von Erfolg und Misserfolg in der Kommunikationswissenschaft. In: Medien \& Kommunikationswissenschaft, v. 59, n. 4, p. 563-580, 2011.

NOELLE-NEUMANN, Elisabeth. Meinung und Meinungsführer. Über den Fortschritt der Publizistikwissenschaft durch Anwendung empirischer Forschungsmethoden. In: Publizistik, v. 8, n. 4, p. 316-323, 1963.

NOELLE-NEUMANN, Elisabeth. Publizistik- und Kommunikationswissenschaft. Ein Wissenschaftsbereich oder Themenkatalog? In: Publizistik, v. 19/20, n. 3, p. 743-748, 1975.

NOELLE-NEUMANN, Elisabeth. Über den Fortschritt der Publizistikwissenschaft durch Anwendung empirischer Forschungsmethoden. Eine biographische Aufzeichnung. In: KUTSCH, Arnulf; PÖTTKER, Horst (eds.). Kommunikationswissenschaft - autobiographisch. Zur Entwicklung einer Wissenschaft in Deutschland. Opladen: Westdeutscher Verlag, p. 36-61, 1997.

NOELLE-NEUMANN, Elisabeth; SCHULZ, Winfried (eds.). Das Fischer Lexikon. Publizistik. Frankfurt/Main: Fischer Taschenbuch, 1971.

NOELLE-NEUMANN, Elisabeth; SCHULZ, Winfried; WILKE, Jürgen (eds.). Das Fischer Lexikon. Publizistik. Massenkommunikation. Frankfurt/Main: Fischer Taschenbuch, 1989.

PÖTTKER, Horst. Gerhard Maletzke, Psychologie der Massenkommunikation. Theorie und Systematik (1963). In: HOLTZ-BACHA, Christina; KUTSCH, Arnulf (eds.). Schlüsselwerke für die Kommunikationswissenschaft. Wiesbaden: Westdeutscher Verlag, p. 289-291, 2002.

PRAKKE, Henk; DRÖGE, Franz; LERG, Winfried B.; SCHMOLKE, Michael. Kommunikation der Gesellschaft. Einführung in die funktionale Publizistik. Münster: Regensberg, 1968.

RONNEBERGER, Franz.Zur Lage der Publizistikwissenschaft. In:LangenbucherWolfgang R. (eds.). Publizistik- und Kommunikationswissenschaft. Ein Textbuch zur 
Einführung in ihre Teildisziplinen. Wien: Wilhelm Braumüller, p. 82-89, 1986.

RONNEBERGER, Franz. Medienforschung und Medienentwicklung von der Nachkriegszeit bis heute. In: Rundfunk und Fernsehen, v. 39, n. 1, p. 7-16, 1991.

SAXER, Ulrich. Von wissenschaftlichen Gegenständen und Disziplinen und den Kardinalsünden der Zeitungs-, Publizistik-, Medien-, Kommunikationswissenschaft. In: SCHNEIDER, Beate; REUMANN, Kurt; SCHIWY, Peter (eds.). Publizistik. Beiträge zur Medienentwicklung. Festschrift für Walter J. Schütz. Konstanz: UVK, p. 39-55, 1995.

STÖBER, Rudolf.Emil Dovifat, Karl d'EsterundWalterHagemann.DieWiederbegründung der Publizistik in Deutschland nach 1945. In: Medien \& Zeit, v. 17, n. 2-3, p. 6784, 2002.

WESTERBARKEY, Joachim. Daten zur Lage des Faches. Eine bestürzende Bilanz. In: Publizistik, v. 25, n. 4, p. 484-491, 1980.

WESTERBARKEY, Joachim. Henk Prakke, Kommunikation der Gesellschaft. Einführung in die funktionale Publizistik (1968). In: HOLTZ-BACHA, Christina; KUTSCH, Arnulf (eds.). Schlüsselwerke für die Kommunikationswissenschaft. Wiesbaden: Westdeutscher Verlag, p. 352-353, 2002.

WIEDEMANN, Thomas. Walter Hagemann. Aufstieg und Fall eines politisch ambitionierten Journalisten und Publizistikwissenschaftlers. Köln: Herbert von Halem, 2012.

WILKE, Jürgen. Von der "entstehenden" zur "etablierten" Wissenschaft. Die institutionelle Entwicklung der Kommunikationswissenschaft als universitäre Disziplin. In: HOLTZ-BACHA, Christina; KUTSCH, Arnulf; LANGENBUCHER, Wolfgang R.; SCHÖNBACH, Klaus (eds.). 50 Jahre Publizistik. Wiesbaden: VS, p. 317-338, 2005/06.

Recebido em: 4/7/2016

Aceito em: 4/7/2016

Endereço dos autores:

Erik Koenen <ekoenen@uni-bremen.de>

Universidade de Bremen

Biblioteca Straße 1

28359 Bremen - Alemanha

Christina Sanko <sanko@uni-bremen.de>

Universidade de Bremen

Biblioteca Straße 1

28359 Bremen - Alemanha 